(C) The Author(s), 2021. Published by Cambridge University Press for the Arizona Board of Regents on behalf of the University of Arizona. This is an Open Access article, distributed under the terms of the Creative Commons Attribution licence (http://creativecommons.org/licenses/by/4.0/), which permits unrestricted re-use, distribution, and reproduction in any medium, provided the original work is properly cited.

\title{
RADIOCARBON DATES FROM THE MONASTERY ON KOM H IN OLD DONGOLA (SUDAN) AND THE CHRONOLOGY OF MEDIEVAL NUBIAN POTTERY
}

\author{
Dorota Dzierzbicka $^{1 *}$ (1) Katarzyna Danys ${ }^{2}$ (D) \\ ${ }^{1}$ Polish Centre of Mediterranean Archaeology, University of Warsaw, ul. Prosta 69, 00-838 Warsaw, Poland \\ ${ }^{2}$ Faculty of Archaeology, University of Warsaw, Krakowskie Przedmieście 26/28, 00-927 Warsaw, Poland
}

\begin{abstract}
The paper presents and discusses a series of radiocarbon $\left({ }^{14} \mathrm{C}\right)$ dates from a medieval Nubian monastery found on Kom H of Old Dongola, the capital of the kingdom of Makuria located in modern-day Sudan. The monastery was founded in the 6th-7th century AD and although it probably ceased to function in the 14th century, the site remained occupied until the beginning of the 15th century. The investigated courtyard of the monastery was in use from the 11 th to the 14th century, as indicated by the ceramics and ${ }^{14} \mathrm{C}$ analysis results presented here. The dates under consideration are the first published series of ${ }^{14} \mathrm{C}$ dates from this site, which is of crucial importance for historical research on medieval Nubian Christianity and monasticism. They permit to begin building an absolute chronological framework for research on the archaeological finds from the site and region. A group of finds in particular need of such a framework are ceramics, and the implications of the ${ }^{14} \mathrm{C}$ dates for pottery assemblages found in the dated contexts are discussed. The conclusions summarize the significance of the datings for the history of the site.
\end{abstract}

KEYWORDS: Makuria, medieval, monastery, Nubia, pottery.

\section{INTRODUCTION}

\section{Overview and Objectives}

The aim of this paper is to present and discuss a series of radiocarbon $\left({ }^{14} \mathrm{C}\right)$ dates obtained in 2017 for material from excavations in Courtyard A at the Monastery on Kom $\mathrm{H}$ in Old Dongola, the capital of the medieval Christian kingdom of Makuria in modern-day Sudan (Figures 1 and 2). The dates in question are important for several reasons. Primarily, this is the first series of dates from Kom $\mathrm{H}$, the site of a large and prosperous monastery located on the edge of Makuria's capital. Second, the dates are instrumental in building an absolute chronology of the pottery assemblages recovered from the excavated layers, as no such chronological framework has thus far been established for locally produced wares. Third, the ${ }^{14} \mathrm{C}$ dates place the excavated structures, somewhat atypical in themselves, firmly in the history of the monastery and in the architectural trends current in medieval Nubia.

In the Dongola Reach, a region encompassing the Middle Nile Valley between the 3rd and the 4 th Cataracts, samples for ${ }^{14} \mathrm{C}$ dating have been collected during numerous surveys and excavations, but most are only briefly mentioned in field reports. Sampling has been reported especially for surveys in the 4th Cataract area (e.g., Paner and Pudło 2010; Żurawski 2007: 325) and works in the Wadi Abu Dom (e.g., Eigner and Karberg 2011: 8182; Obłuski et al. 2017: 373). A noteworthy series of ${ }^{14} \mathrm{C}$ and OSL dates discussed in detail was obtained at Boni Island in the 4 th Cataract region, producing an occupation sequence that spanned from the Neolithic to the Late Christian period (Wotzka et al. 2012). Eleven of these samples were contemporary to Courtyard A on Kom H at Old Dongola (Wotzka et al. 2012: 149). However, these dates were not discussed in correlation with pottery finds. In addition, three ${ }^{14} \mathrm{C}$ dates published for Jebel Kadamusa in the 3rd Cataract area were

\footnotetext{
*Corresponding author. Email: d.dzierzbicka@uw.edu.pl.
} 


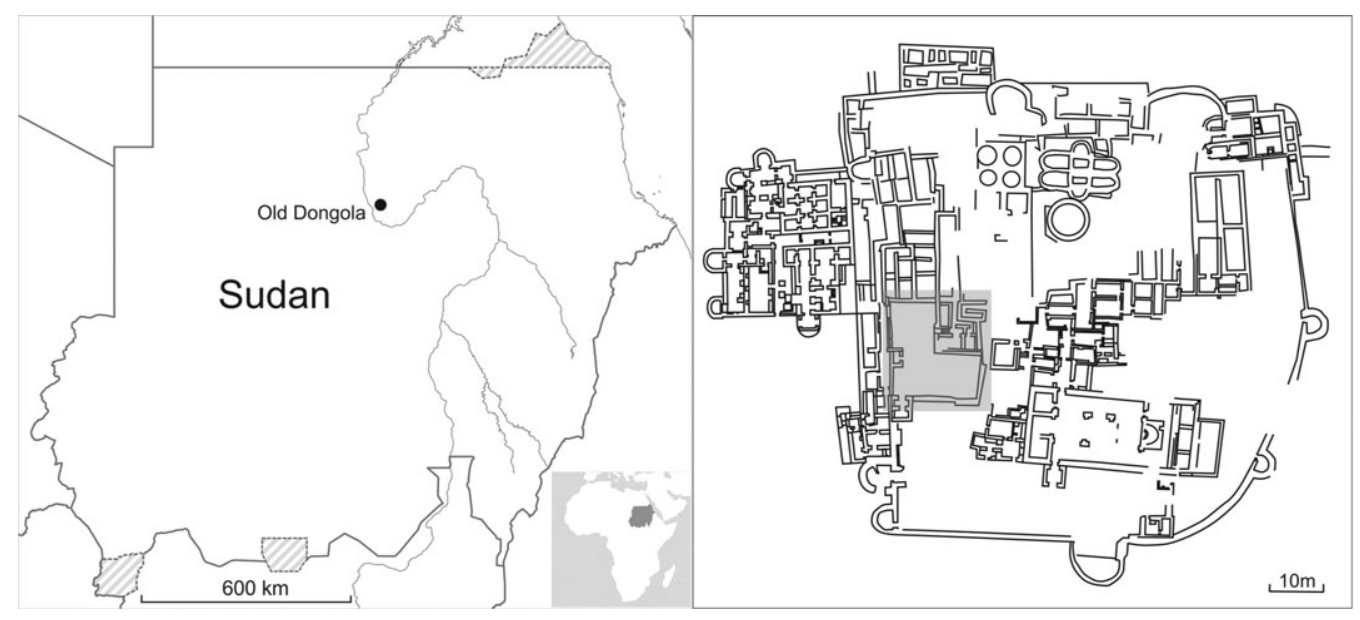

Figure 1 Geographic location of Old Dongola (left) and situation of Courtyard A in the monastery on Kom H (right).

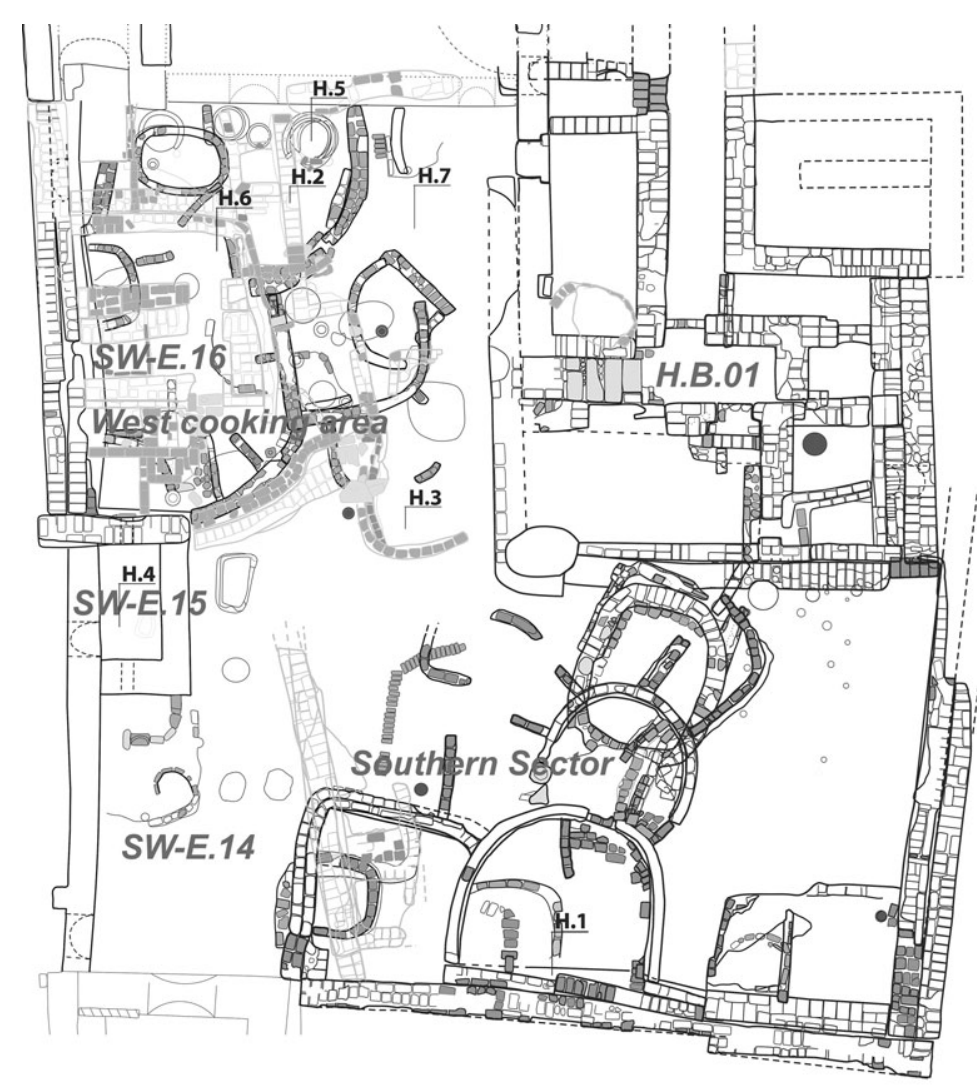

0 $5 \mathrm{~m}$

Figure 2 Cumulative plan of Courtyard A at the monastery on Kom H in Old Dongola showing the locations of sample collection (drawn by A Deptuła, D Dzierzbicka, and S Lenarczyk; courtesy of PCMA UW). 
discussed in detail, but they fall outside the dating span of the monastery on Kom $\mathrm{H}$ (Hamilton 2012).

At Old Dongola, no series of ${ }^{14} \mathrm{C}$ dates have been published, and only isolated samples have been analyzed and mentioned in reports (e.g., Godlewski 2015: 19; Godlewski et al. 2015: 84). At the nearby pilgrimage site of Banganarti, collected samples await analysis (Drzewiecki 2010: 432, 2017: 308), while at the medieval settlement of Hambukol near Old Dongola, six dates, the latest being $1295 \pm 45$, were briefly presented in an archaeological report (Grzymski 1990: 163; Table 1). Therefore, a discussion of the seven dates from Kom $\mathrm{H}$ in Old Dongola may contribute to building a more secure chronology of both site and region. Detailed presentation and discussion of ${ }^{14} \mathrm{C}$ dates of contexts in correlation with pottery analyses constitutes a combined method of study not used before in research on the medieval period in the Dongola Reach.

\section{Site Description}

Activity at the monastery on Kom $\mathrm{H}$ in Old Dongola is dated from the 7 th to the 14 th century AD (Jakobielski 2008) or more broadly from the 6th to the 15th century AD (Godlewski 2018) on the basis of pottery finds, inscriptions, and historical data. The monastic site has been excavated by an archaeological mission of the Polish Centre of Mediterranean Archaeology, University of Warsaw, since 1991. In the course of nearly three decades, the team uncovered, among other things, a monastic church (Gazda 2008), tombs of archbishops of Dongola (Żurawski 1999; Lajtar and Vliet 2017), and a series of chapels decorated with wall paintings (Martens-Czarnecka 2011). Fieldwork has also uncovered several monastic buildings (e.g., Jakobielski 2001: 22-25, 2010).

Most recently, the excavations focused on the so-called Courtyard A (Figures 1 and 2), located in the southwest part of the monastery. This area has not been investigated to date, with the exception of two structures referred to in previous scholarship as SW-E.15 and SW-E.16 and a small open area SW-E.14, the late strata of which had been excavated by Stefan Jakobielski (Jakobielski 2010: 83, Fig. 82; Jakobielski and Martens-Czarnecka 2008: 331-334 and 326; Figure 1). Courtyard A is a deep-stratified open area with numerous superimposed installations and structures attributable to multiple phases of use. The courtyard seems to have been a service area used primarily for storage and food processing. Its position near a side entrance to the monastery, coupled with an abundance of storage vessels found in the deposits, indicate its role as a delivery point for supplies brought to the complex (Dzierzbicka and Deptuła 2018).

\section{METHOD}

\section{Excavation and Sampling}

Excavations in Courtyard A were carried out using the stratigraphic method, with respective layers distinguished either on the basis of their morphological traits such as color, texture and composition, or arbitrarily, if foundation levels of structures suggested changes in occupational phase. Samples were collected from strata rich in organics (wood, chaff, reeds, palm, animal dung, etc.) and burnt matter, as well as from wooden elements of structures. The structures, deposits and finds excavated in the courtyard were analyzed and grouped on stratigraphic grounds into 10 occupational phases discussed in more detail in an interim excavation report (Dzierzbicka and Deptuła 2018). The phases were then combined into three superimposed, 
Table 1 Samples from Courtyard A, size, yield, and age.

\begin{tabular}{|c|c|c|c|c|c|c|c|c|c|c|c|c|}
\hline Sample code & Sample name & Material & $\begin{array}{l}\text { To comb } \\
\text { (mg) }\end{array}$ & $\mathrm{C}(\mathrm{mg})$ & AMS date & $\mathrm{pMC}$ & Err. & Age ${ }^{14} \mathrm{C}$ & Err. & $\mathrm{D}^{13} \mathrm{C}(\mathrm{AMS})$ & Err. & $\begin{array}{l}\text { Current } \\
\text { micro AMS }\end{array}$ \\
\hline Poz-100060 & Dongola.H.1 & Wood & n.m. & 0.73 & $4 / 3 / 18$ & 87.95 & 0.3 & 1031 & 27 & -24 & 0.2 & 32.5 \\
\hline Poz-100061 & Dongola.H.2 & Wood & n.m. & 3.31 & $4 / 3 / 18$ & 90.18 & 0.3 & 830 & 26 & -27.2 & 1.1 & 32.7 \\
\hline Poz-99964 & Dongola.H.3 & Charcoal & 3.04 & 2.55 & $3 / 28 / 18$ & 90.22 & 0.35 & 826 & 31 & -31.3 & 0.4 & 27.4 \\
\hline Poz-99967 & Dongola.H.4 & Charcoal & 2.45 & 1.8 & $3 / 28 / 18$ & 90.06 & 0.31 & 841 & 27 & -22.6 & 0.4 & 22.6 \\
\hline Poz-99968 & Dongola.H.5 & Charcoal & 2.6 & 2.07 & $3 / 28 / 18$ & 88.7 & 0.35 & 963 & 31 & -21.8 & 0.4 & 20.4 \\
\hline Poz-99963 & Dongola.H.6 & Charcoal & 2.01 & 1.27 & $3 / 28 / 18$ & 90.45 & 0.31 & 806 & 27 & -24 & 0.8 & 27.9 \\
\hline Poz-100009 & Dongola.H.7 & Charcoal & 2.42 & 1.78 & $3 / 29 / 18$ & 89.64 & 0.37 & 878 & 33 & -25.2 & 0.8 & 23.4 \\
\hline
\end{tabular}


functional development stages in the life of the courtyard: the Open Courtyard stage (phases I-IV); Cooking Area stage (phases V-VII); and Dwelling Complex stage (phases VIIIA and B), followed by some later developments (phases XI and X), the nature of which is obscure due to the poor state of preservation of relics in the uppermost strata.

Of the samples collected during the excavations in Courtyard A, a pilot group of seven was subjected to ${ }^{14} \mathrm{C}$ analysis using the AMS method. The choice of samples was governed by the need to provide absolute dates for the occupational phases of the courtyard; however, no samples were collected from the latest phases, IX and $\mathrm{X}$, as their structures corresponded only to unreliable surface layers and relics of structures, which were very poorly preserved and exposed to contamination.

\section{AMS ${ }^{14} \mathrm{C}$ Dating}

The method of sample processing followed procedures of $\mathrm{AMS}{ }^{14} \mathrm{C}$ dating used in the Poznan Radiocarbon Laboratory (laboratory code designation Poz). Methods of chemical pretreatment at the laboratory generally follow those used in the Oxford Radiocarbon Accelerator Unit (Brock et al. 2010). After mechanical removal of macroscopic contamination visible under binocular, the charcoal and wood samples were treated with $1 \mathrm{M}(\mathrm{UW}, \mathrm{ZR}) \mathrm{HCl}\left(80^{\circ} \mathrm{C}, 20+\mathrm{min}\right), 0.1 \mathrm{M} \mathrm{NaOH}$ at $80^{\circ} \mathrm{C}(\mathrm{UW}, \mathrm{ZR})$ and then $0.25 \mathrm{M}$ $\mathrm{HCl}\left(80^{\circ} \mathrm{C}, 1 \mathrm{hr}\right)$. After treatment with each reagent, the samples were rinsed with deionised water (Millipore) until $\mathrm{pH}=7$. For the first $\mathrm{HCl}$ treatment, a longer time $(20+)$ was applied if emanation of gas bubbles from the sample was still visible. The step of $\mathrm{NaOH}$ treatment was repeated until no more coloration of the $\mathrm{NaOH}$ solution appeared. In case of the two wood samples, H.1 and H.2, additional treatment with $5 \% \mathrm{NaClO}_{2}$ (room temperature, $30 \mathrm{~min}$ ) was applied.

$\mathrm{CO}_{2}$ was produced by combusting the samples. For samples H.1 and H.2, combustion was performed in closed quartz tubes (sealed under vacuum), together with $\mathrm{CuO}$ and $\mathrm{Ag}$ wool, in $900^{\circ} \mathrm{C}$ over $10 \mathrm{hr}$. The obtained gas $\left(\mathrm{CO}_{2}+\right.$ water vapor) was then dried in a vacuum line and reduced with hydrogen $\left(\mathrm{H}_{2}\right)$ using $2 \mathrm{mg}$ of $\mathrm{Fe}$ powder as a catalyst. For samples H.3-H.7, the combustion and reduction of the obtained $\mathrm{CO}_{2}$ was performed with an automated graphitization system, AGE (Wacker et al. 2010), coupled with elemental analyser vario ISOTOPE select (Elementar ${ }^{\mathrm{TM}}$ ). The obtained mixture of carbon and iron was then pressed into a special aluminium holder (Czernik and Goslar 2001).

${ }^{14} \mathrm{C}$ measurements were performed in the AMS ${ }^{14} \mathrm{C}$ Laboratory of the Adam Mickiewicz University, Poznań. The content of ${ }^{14} \mathrm{C}$ in the carbon samples was measured using the Compact Carbon AMS spectrometer produced by the National Electrostatics Corporation, USA (Goslar et al. 2004). The measurement was performed by comparing intensities of ionic beams of ${ }^{14} \mathrm{C},{ }^{13} \mathrm{C}$, and ${ }^{12} \mathrm{C}$ measured for each sample and for standard samples (modern standard: "Oxalic Acid II" and standard of ${ }^{14} \mathrm{C}$-free carbon: "background"). In each AMS run performed at the laboratory, 30-33 samples of unknown age are measured, alternated with measurements of 3-4 samples of modern standard and 1-2 samples of background. In cases where organic samples are dated, as in the case of all Old Dongola samples, the background is represented by coal.

Conventional ${ }^{14} \mathrm{C}$ age was calculated using the correction for isotopic fractionation (Stuiver and Polach 1977: 355), based on the ratio ${ }^{13} \mathrm{C} /{ }^{12} \mathrm{C}$ measured in the AMS spectrometer simultaneously with the ratio ${ }^{14} \mathrm{C} /{ }^{12} \mathrm{C}$. Uncertainty of calculated ${ }^{14} \mathrm{C}$ age was determined 
using uncertainty implied from counting statistics, and also spread (standard deviation) of partial ${ }^{14} \mathrm{C} /{ }^{12} \mathrm{C}$ results, whichever was bigger. Uncertainties of ${ }^{14} \mathrm{C} /{ }^{12} \mathrm{C}$ ratios measured on standard samples were additionally taken into account. The 1- $\sigma$ uncertainty of conventional ${ }^{14} \mathrm{C}$ age given in the laboratory report was the best estimate of the total uncertainty of measurement.

Calibration of ${ }^{14} \mathrm{C}$ age was performed using the program OxCal ver. 4.2 (2014) (Bronk Ramsey 2001, 2009; Bronk Ramsey and Lee 2013). Calibration was performed against the newest version of the ${ }^{14} \mathrm{C}$ calibration curve, i.e., IntCal13 (Reimer et al. 2013). For detailed information on the samples, yields and dates, see Table 1.

\section{Stratigraphic Sequencing}

Independently of the ${ }^{14} \mathrm{C}$ analyses, activity in the courtyard was dated from the 11 th to the early 14th century on the basis of ceramic evidence (Table 3, column "Dongola relative dating system"; see also Danys 2018). The samples can be placed in a relative sequence on the basis of their stratigraphic position, elevation and contextual dating based on pottery data. The samples were collected at elevations ranging from $13.20 \mathrm{~m}$ (sample H.7) to $15.40 \mathrm{~m}$ (sample H.2), ${ }^{1}$ and the layers and structures they come from are horizontally superimposed one on top of the other. Besides some pitting related to occupational activity, primarily the practice of using fire pits in cooking (Dzierzbicka, forthcoming), no major disturbance of the stratigraphy was observed. It was, therefore, possible to place the samples in a relative chronological sequence and to assign them to development stages distinguished in the excavated area.

Five of the samples come from contexts that had established stratigraphic relationships to one another and therefore formed a chronological sequence in the following order, from earliest to latest: H.7 - H.3 - H.6 - H.5 - H.2. Two samples are outliers collected in other parts of the excavated area. The context of sample H.1 is part of the stratigraphic sequence of the courtyard area placing it after H.7 and before H.3, but it was retrieved from a different area of the courtyard and did not have a direct relationship to the contexts of the samples listed above. Sample H.4 was collected from a layer that was separated from the courtyard area (excavated within room SW-E.15) but linked to phase VIIIA by the presence of matching fragments of the same vessel in the context of the sample and in the floor of complex SW-E.16.

\section{Pottery Collection and Processing}

The pottery discovered during excavations in Courtyard A was studied in order to achieve two main goals: (1) to establish a general dating for the phases of occupation in Courtyard A, and (2) to determine the function of the uncovered ceramic objects and their role in the excavated area. The finds were grouped according to their stratigraphic position, allowing to establish their relative chronology.

The study of the pottery followed procedures typically used for recording mass material: quantification was carried out using the so-called RHBS method, or counting all sherds: so-called diagnostic fragments, Rims, Bases, and Handles, as well as Sherds, or

\footnotetext{
${ }^{1}$ For the sake of compatibility with earlier documentation and reports, the height measurements taken in Old Dongola in seasons 2014-2017 conformed to a local grid system that refers to the 1964 geodetic vertical datum based on the level of the River Nile in Dongola (Michałowski 1966). The elevation quota for Courtyard A are, therefore, not absolute values above sea level.
} 
non-diagnostic fragments (for a full description of procedures used in the processing and study of the ceramics from Courtyard A, see Danys 2018).

The complete pottery assemblage from Courtyard A comprised 48,760 fragments of ceramics, including 10\% diagnostic and 90\% non-diagnostic sherds. The finds were sorted according to technological criteria into wheel-made and handmade vessel groups (95\% and 5\% resp.). Subsequently, they were divided into the following general groups based on functional and technological grounds: wheel-made utility ware (WMUW), handmade vessels for storage, food preparation, serving and cooking purposes (HMSV, HMFSP, HMCP), wheel-made tableware (TW), and wheel-made transport containers (TC). Other groups of ceramic finds included handmade and wheel-made objects such as lamps, pot-stands, fire-dogs, pipes, heaters/trays/boxes, and unfired storage containers/bins (for a more detailed description of the ceramics categories, see Danys 2018).

The largest pottery group in Courtyard A was transport containers. It comprised various types of vessels: amphorae, jars, bottles, and flasks. The vessels were mostly preserved as nondiagnostic fragments, in contrast to, for instance, tableware, in which diagnostics were prevalent. Variation in the state of vessel preservation made it necessary to use the RHBS method, in which all fragments are recorded and analyzed.

The less numerous groups of material were wheel-made utility ware and handmade vessels for storage, food preparation, serving and cooking purposes. The category "other" comprised a variety of vessels and objects made of baked and unbaked clay of different functions. The last group was composed of fragments that could not be unambiguously assigned to the above categories or were too poorly preserved, eroded or worn.

\section{RESULTS}

\section{Archaeological Contexts}

The obtained ${ }^{14} \mathrm{C}$ analysis results are discussed below in chronological order, in correlation with the three main functional stages of development of the excavated space. The sample descriptions (material, context, elevation, and phase) and their dates are presented in Table 2 and Figure 3. Locations in which the samples were collected are marked on the plan in Figure 2.

Since the material of all the samples is wood, an important issue to consider is whether the age of the wood reflects the age of its context. Five samples are pieces of charcoal from daily cooking and baking activity, while H.1 and H.2 are fragments of palm wood posts. The age of a palm tree itself is not an issue; palms may grow to be centuries old, but the stem xylem, phloem, and parenchyma cells remain alive for the life of the palm (Tomlinson and Huggett 2012). An issue to consider, however, is reuse of old wood. Recycling discarded palm wood trunks as roof supports of structures in the courtyard cannot be excluded. Refurbishments and alterations to monastic buildings could have provided old beams fit for reuse. In such a case, the date of the sample could even be several centuries earlier than the excavated context. Charcoal fragments recovered from contexts related to cooking activity pose a smaller problem in this respect, as these small fires usually seem to have been fuelled by shrubs and small branches rather than old trees. However, also in this case the use of old wood, whether directly cut-down trees or old wooden objects, cannot be excluded. 
Table 2 Samples from Courtyard A, context and dating

\begin{tabular}{|c|c|c|c|c|c|c|c|}
\hline $\begin{array}{l}\text { Sample } \\
\text { code }\end{array}$ & Sample no. & Material & Context & Phase & ${ }^{14} \mathrm{C}$ age $\mathrm{BP}$ & cal AD 92-96\% & cal AD $68.2 \%$ \\
\hline Poz-100061 & Dongola.H.2 & Wood & $\begin{array}{l}\text { F26, central palm wood } \\
\text { post, elev. c. } 15.40 \mathrm{~m}\end{array}$ & VIIIB & $830 \pm 30 \mathrm{yr}$ & $\begin{array}{c}1161-1264 \\
(95.4 \%)\end{array}$ & $1188-1251$ \\
\hline Poz-99967 & Dongola.H.4 & Charcoal & Layer 66, elev. $13.30 \mathrm{~m}$ & VIIIA & $840 \pm 30 \mathrm{yr}$ & $\begin{array}{c}1154-1264 \\
(95.4 \%)\end{array}$ & $\begin{array}{c}1166-1224 \\
(63.5 \%) ; \\
1235-1241(4.7 \%)\end{array}$ \\
\hline Poz-99968 & Dongola.H.5 & Charcoal & $\begin{array}{l}\text { Layer } 47 \text {, inside oven } \\
\text { F102, elev. c. } 14.80 \mathrm{~m}\end{array}$ & VI & $965 \pm 35 \mathrm{yr}$ & $\begin{array}{c}1015-1160 \\
(95.4 \%)\end{array}$ & $\begin{array}{c}1022-1050 \\
(24.2 \%) ; \\
1084-1125 \\
(33.2 \%) ; \\
1136-1151 \\
(10.8 \%)\end{array}$ \\
\hline Poz-99963 & Dongola.H.6 & $\begin{array}{c}\text { Charred wooden } \\
\text { spindle whorl } \\
\text { HDd. } 16.267\end{array}$ & Layer 56, elev. c. $14.50 \mathrm{~m}$ & VI & $805 \pm 30 \mathrm{yr}$ & $\begin{array}{c}1181-1273 \\
(94.2 \%)\end{array}$ & $1217-1261$ \\
\hline Poz-99964 & Dongola.H.3 & Charcoal & Layer 29 , elev. c. $14.30 \mathrm{~m}$ & V & $825 \pm 35 \mathrm{yr}$ & $\begin{array}{c}1156-1272 \\
(95.4 \%)\end{array}$ & $1190-1257$ \\
\hline Poz-100060 & Dongola.H.1 & Wood & $\begin{array}{l}\text { Room 1, palm wood post } \\
\text { supporting roof, elev. c. } \\
13.50 \mathrm{~m}\end{array}$ & III & $1030 \pm 30 \mathrm{yr}$ & $\begin{array}{c}962-1041 \\
(91.9 \%)\end{array}$ & $989-1023$ \\
\hline Poz-100009 & Dongola.H.7 & Charcoal & Layer 95 , elev. c. $13.20 \mathrm{~m}$ & I-II & $880 \pm 35 \mathrm{yr}$ & $\begin{array}{c}1039-1224 \\
(95.4 \%)\end{array}$ & $\begin{array}{l}1052-1081 \\
(17.7 \%) \\
1152-1215 \\
(50.5 \%)\end{array}$ \\
\hline
\end{tabular}




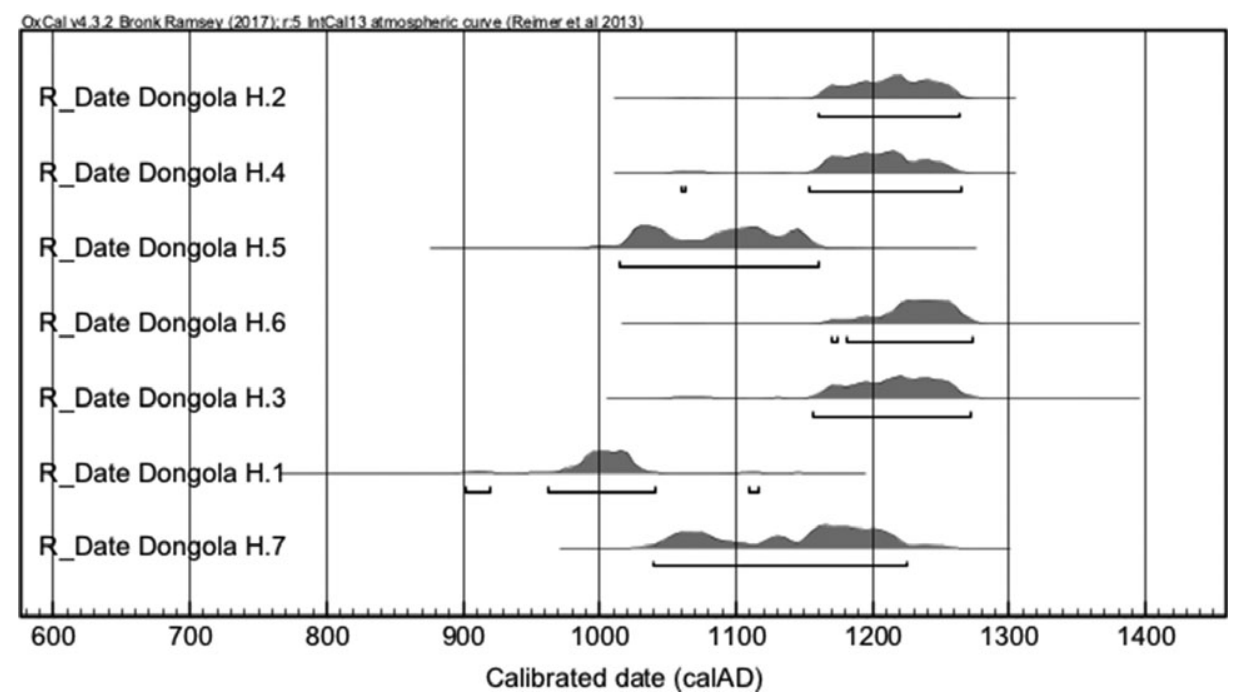

Figure 3 Calibrated dates of the samples from Courtyard A (OxCal v.2.3.2 [Bronk Ramsey 2017]; r.5 IntCal13 atmospheric curve [Reimer et al. 2013]).

The presented conclusions are of a preliminary nature due to the small number of samples subjected to analysis. Each of the seven samples represents a different phase, therefore the basis for dating individual phases is too slim, taking into account possible errors, and in this respect the results must be treated with caution. The dating span of the individual phases is impossible to infer from the individual ${ }^{14} \mathrm{C}$ ages of the samples. However, we may at least draw preliminary conclusions concerning the chronological span of Courtyard A as a whole and speculate about the dating of its main stages, combining the stratigraphic data with pottery datings and ${ }^{14} \mathrm{C}$ results. A statistical model considering the chronology of the samples and their respective phases is presented in Figure 4.

\section{Samples from the Open Courtyard Stage (Phases I-IV)}

In the earliest occupational stage, Courtyard A was an open space, which gave access to monastic buildings (the so-called Main Building and H.B.01) in the northern part. Over time, it began to fill with ovoid structures built for dwelling or storage purposes. Two samples, H.1 and H.7, belong to this occupational stage.

Sample H.7 is a charcoal fragment from layer 95 (elevation ca. $13.20 \mathrm{~m}$ ), one of the earliest strata excavated throughout the Courtyard A, contemporary to the functioning of building H.B.1. The $95 \%$ confidence interval for the date of the sample ranges from the mid-11th to first half of 13 th century. Based on stratigraphic grounds and pottery data we could narrow this range down to the mid-11th to 12 th century.

Sample H.1 is a fragment of a palm-wood post (elevation ca. $13.50 \mathrm{~m}$ ) that supported the roof of Room 1, an ovoid structure erected of re-used material against the south wall of the courtyard. The ${ }^{14} \mathrm{C}$ date falls in an interval from the late 10 th to early 11 th century AD. According to the stratigraphy, Room 1 was the first of ovoid structures in the courtyard, but this range seems early given the dating of sample H.7 discussed above. 


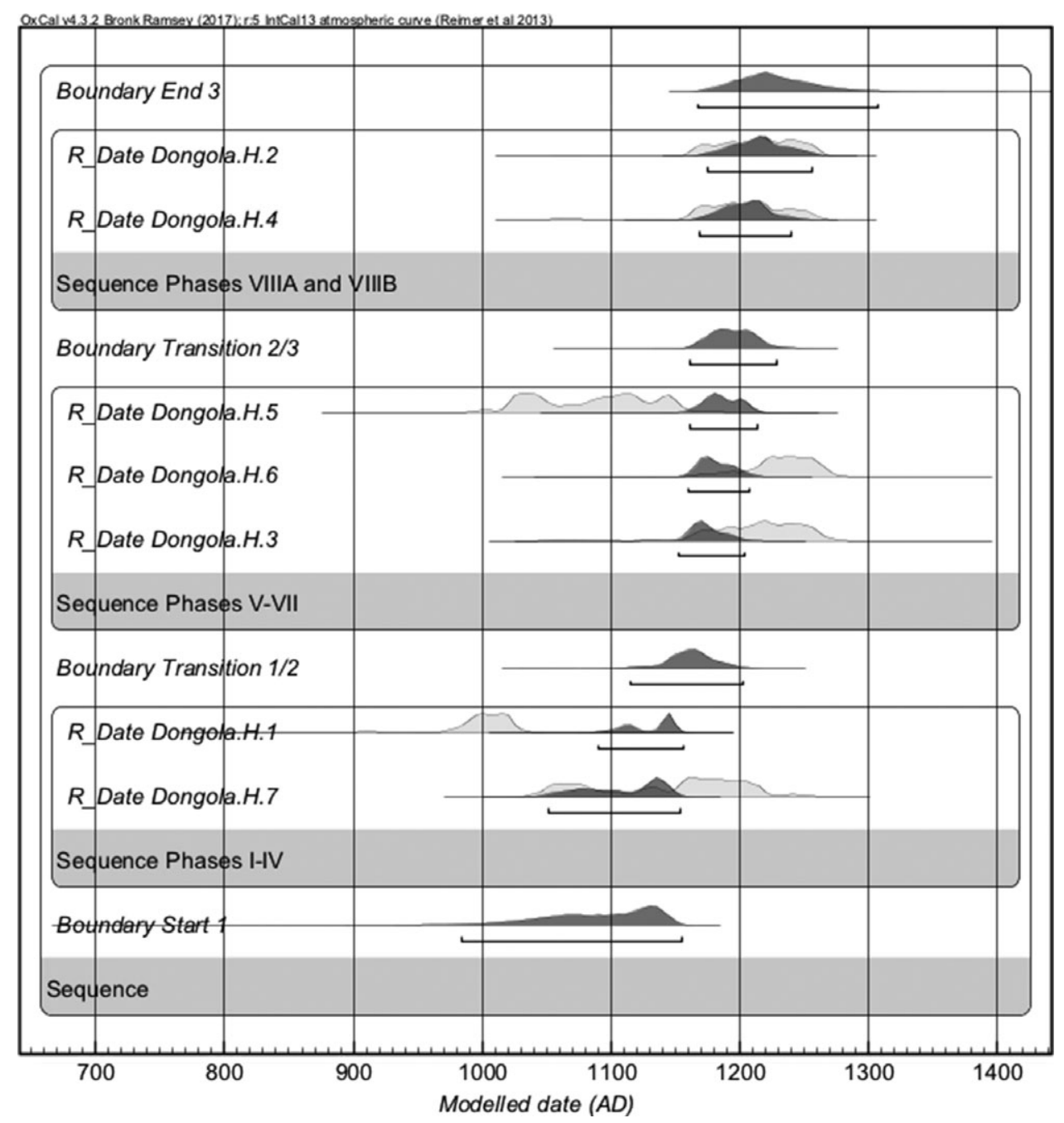

Figure 4 Statistical model showing the chronological sequence of calibrated dates of samples from phases I-VIIIA (OxCal v.2.3.2 [Bronk Ramsey and Lee 2013; Bronk Ramsey 2017]; r.5 IntCal13 atmospheric curve [Reimer et al. 2013]).

The ${ }^{14} \mathrm{C}$ dating is of the palm-wood post, not the structure itself, so in this case we may be dealing with the old wood effect. Relics of decomposed palm-wood beams have been found in situ elsewhere on the site (e.g., Jakobielski 1997), which indicates that palm, readily available in the area, was not necessarily reclaimed for re-use from older buildings. However, such re-use cannot be excluded and, given the early ${ }^{14} \mathrm{C}$ date span of the sample, it is indeed likely. It is impossible to determine how much older the roof support was from the structure, but the dating of the wood may be treated as a terminus post quem. Room 1 was probably not erected before the mid-11th or even 12 th century $\mathrm{AD}$, given the probable date of sample H.7. Overall, therefore, the ${ }^{14} \mathrm{C}$ dating of the two samples may point to early use of Courtyard A as an open space since the mid-11th century AD and through the 12th century AD. 


\section{Samples from the Cooking Area Stage (Phases V-VII)}

In an intermediate stage of use, a series of cooking installations (ovens, baking spaces, fire pits, storage containers) were built in the northwest quadrant of the courtyard. The cooking space was partly covered with a light roof and walled off from the rest of the open area. At the same time, ovoid rooms in the south part were also adapted for food processing purposes (Dzierzbicka and Deptuła 2018). The three samples come from a sequence of contexts ranging in elevation from ca. $14.30 \mathrm{~m}$ to ca. $14.80 \mathrm{~m}$. The pottery dating of the Cooking Area is ca. the 13th century AD.

Sample H.3, a charcoal fragment, is dated within an interval from the mid 12 th to second half of 13 th century AD. The context from which it was recovered (elevation $14.30 \mathrm{~m}$ ) lay outside the wall enclosing the cooking area, but abutted its wall and was considered contemporary to its functioning.

Sample H.6 is a charcoal fragment from layer 56 (elevation ca. $14.50 \mathrm{~m}$ ), a late layer of the Cooking Area stage excavated at the interface of the West Cooking Area and the overlying dwelling complex SW-E.16 (see below). The sample date was calibrated to a $95 \%$ confidence interval spanning from late 12 th to second half of 13 th century AD.

Sample H.5 is a charcoal fragment from layer 47 (elev. ca. $14.80 \mathrm{~m}$ ), a deposit excavated inside oven F102 in the Cooking Area. According to the ${ }^{14} \mathrm{C}$ analysis, the most probable intervals of calendar age are the 1 st half of the 11 th or the 2 nd half of the 11 th to the first half of the 12 th century AD. Both are remarkably early, given the intervals for samples H.3 and H.6, collected at lower levels. A possible explanation could be the use of old wooden objects as fuel for the oven. All in all, the ${ }^{14} \mathrm{C}$ datings do not contradict the 13 th-century $\mathrm{AD}$ date of the Cooking Area stage proposed on the basis of pottery finds.

\section{Samples from the Dwelling Complex Stage (Phases VIII A and B) and Refuse Dump Inside SW-E.15}

The latest layers excavated in this area of Courtyard A belong to a complex of rooms codenamed SW-E.16, built on top of the demolished cooking area against the west wall, and to a refuse dump inside an adjacent abandoned room SW-E.15. The contemporary layers to the east of the complex are heavily eroded and pitted, and no structures are preserved.

Sample H.4 is a charcoal fragment from layer 66, the lowest stratum of a rubbish dump in room SW-E.15. The dating within a $95.4 \%$ probability range from the mid-12th to the second half of 13 th century AD gives support to the hypothesis that the refuse dump was contemporary to the functioning of the dwelling SW-E.16 in phase VIIIA and was used by its inhabitants. Furthermore, this is interesting evidence for the practice of depositing trash in ground-floor rooms of older buildings that had fallen into disuse. Phase VIIIA need not have lasted long and may have occurred in the second half of the 13th century AD.

Sample H.2 (elevation ca. $15.40 \mathrm{~m}$ ) was collected from a palm-wood post embedded in a wall belonging to a late phase of dwelling SW-E.16. Its date falls with $95.4 \%$ probability in an interval spanning from the second half of 12 th to second half of 13 th century AD and can be considered the post quem date of the dwelling phase VIIIB. As with sample H.1, the palm-wood post could predate the structures assigned to phase VIIIB, which may have been erected closer to the end of the 13th century or even in the 14th century AD, to judge by the ceramic evidence. 


\section{Ceramic Studies}

The ceramic assemblage from Courtyard A represents a vast array of pottery belonging to the local, Dongolese ceramic tradition. It features a multitude of vessel forms used for a variety of purposes. An examination of the finds revealed a domination of pottery connected with the main function of this space: distribution and storage of goods delivered to the monastery.

Most of the tableware represented the early phase of the excavated area, when it was an open space with no structures erected yet, or a later phase when consumption also took place on this spot. The western cooking area phase, with its various food processing installations, is associated with handmade vessels used for storage, food preparation, serving and cooking, and then reused for other purposes (e.g., broken cooking pots served as pot-stands for other vessels).

Courtyard A also lay at an intersection of paths leading to different parts of the monastery, as well as to the outside. Some of the ceramic finds might have been rubbish discarded there by the passing inhabitants of the monastery or monastic servants working in this area.

\section{DISCUSSION}

\section{Chronology of Nubian Pottery and the ${ }^{14} \mathrm{C}$ Dates from Courtyard A}

The dating of the ceramic assemblage from Courtyard A was based on typological and stylistic analyses of vessel shapes and decorative elements. The main point of reference was the general framework for the study of medieval Nubian pottery established by W.Y. Adams (1986). In his seminal work, Adams provided a chronological guide, a key to the identification and dating of Nubian archaeological sites on the basis of ceramic finds. This relative dating was based on stratigraphy or superposition of the pottery assemblages discovered during the Nubian UNESCO campaigns in the 1960s. Given the absence of ${ }^{14} \mathrm{C}$ dates, the only way to build relative chronologies for pottery finds was the study of settlement sites with long occupational histories aided by historical and textual sources. Estimating the length of respective time periods within the chronological framework, Adams also took into account the relative thickness of stratigraphic deposits and the number of different levels. The chronological system for Christian pottery is divided into five periods: Early, Classic, PostClassic, Late, and Terminal. The general categories of ceramics ("Pottery Families") dated to the above periods were further subdivided into wares, and also decorative styles were introduced into the chronological sequences as an additional dating factor. As a result, the time spans for individual groups of ceramics sometimes extend beyond the date ranges established for the respective periods. For example, Ware U10, a Pink Utility Ware (which seems to be a parallel to the specimens classed as TC and WMUW from Courtyard A) dated to the Late Christian period (1200-1400), appears first around 850 AD, its main period of manufacture is dated to $1000-1500 \mathrm{AD}$, and it remains in use as late as $1600 \mathrm{AD}$ (Adams 1986: 523, 601-616). Such a broad chronological span was due to contamination of archaeological contexts, e.g., pits dug into earlier deposits. Adams additionally took into account errors caused by implicitness in field methodology and problems with interpretation. Exploration of arbitrary levels instead of single contexts using the stratigraphic method of excavation further contributed to the creation of a very broad chronological framework. Nonetheless, the observation of changes in decoration permitted a more precise dating. It was this division into styles of decoration that was key for the phasing of the ceramics from Dongola. 
Table 3 Collation of phases, chronology of the ceramics, and ${ }^{14} \mathrm{C}$ datings in Courtyard $\mathrm{A}$ in Old Dongola

\begin{tabular}{|c|c|c|c|}
\hline $\begin{array}{l}\text { Courtyard A } \\
\text { occupation } \\
\text { phase }\end{array}$ & $\begin{array}{l}\text { Old Dongola relative } \\
\text { dating system (Danys } \\
\text { 2018) }\end{array}$ & $\begin{array}{l}\text { Adams Decorative Styles } \\
\text { dating system (1986: fig } \\
100)\end{array}$ & $\begin{array}{l}{ }^{14} \mathrm{C} \text { samples and } \\
\text { stratigraphy } \\
\text { dating }\end{array}$ \\
\hline VIIIB & 13th-beg. 14th c. & N.VII ? (1350-1500 AD) & $\begin{array}{l}\text { End of the } 13 \text { th } \\
\text { to early } 14 \text { th } \mathrm{c} \text {. }\end{array}$ \\
\hline VIIIA & $\begin{array}{l}\text { End of the } 12 \text { th } \\
\text { through } 13 \text { th } \mathrm{c} .\end{array}$ & N.VIA (1150-1350 AD) & Late 13 th $\mathrm{c}$. \\
\hline VI-VII & 13 th c. & N.VIA (1150-1350 AD) & 13th c. \\
\hline V & 13th c. & N.VIA (1150-1350 AD) & 13th c. \\
\hline III & 11 th-12th $\mathrm{c}$. & N.VA (1000-1150 AD) & 12th c. \\
\hline I-II & 11 th-12th c. & $\begin{array}{l}\text { N.VA (1000-1150 AD), } \\
\quad \text { N.VIA (1150-1350 AD) }\end{array}$ & Mid-11th-12th c. \\
\hline
\end{tabular}

Adams's publication was treated as a reference in the study of pottery from Courtyard A despite the fact that the Dongolese material represents an Upper Nubian pottery production, while ceramics investigated by W.Y. Adams came from Lower Nubia, the area between the 1st and 2nd Cataracts on the Nile. In many cases the wares, vessel shapes, and decorative motifs found in the ceramic assemblage from Old Dongola differ from their Lower Nubian counterparts or are altogether absent from Adams's typology. Also, Dongola was a major pottery-manufacturing center in the medieval period (Pluskota 2001), so local chronological sequences of ceramics need to be taken into consideration. Therefore, parallel to the seminal work of W.Y. Adams, the research on local ceramics conducted to date (Pluskota 2001, 2005; Danys 2016 and in preparation) serve as a basis for periodization of the ceramics from Courtyard A. In addition to Adams's chronological system, the assemblages stratigraphically recovered during excavations in Dongola permit to build a more precise and site-specific dating sequence, especially useful when dealing with undecorated fragments. The two systems-Adams's chronology and the Dongola chronology-were used in tandem to establish the datings for the ceramics from Courtyard A (see Table 3). The series of ${ }^{14} \mathrm{C}$ dates from different stratigraphic deposits in this area help anchor the relative chronologies in a framework of absolute dates.

\section{Courtyard Phases and Their Broader Context}

The three main chronological phases distinguished on the basis of stratigraphic data and ceramic evidence in correlation with the ${ }^{14} \mathrm{C}$ dates can tentatively be given an absolute chronology: The Open Courtyard phase (strat. phases I-IV) spanned from ca. the mid11 th through the 12th century AD; the Cooking Area phase (strat. phases V-VII) through the first half and middle of the 13th century AD; and the building and occupation of SW-E.16 (strat. phases VIII A and B) from the second half of the 13th century into the 14th century AD.

The above allows placement of the activity in Courtyard A within the broader context of the monastery. The earliest activity in the area of Courtyard A may be dated to the mid-11th century AD. The dating of the Open Courtyard stage (mid-11th-12th century AD), with its passageway through the west wall to a ground floor corridor connecting the Northwest and 
Southwest Annexes, is contemporary to several dynamic developments in the monastery, which are dated on the basis of epigraphic sources. The first half of the 12th century AD is the time of building the crypt of the archbishop Georgios who died in 1113 AD (Lajtar 2002; Lajtar and Vliet 2017) and new construction projects in the Northwest Annex including the chapels of Archangel Michael and Zacharias (Godlewski 2013: 671-675) as well as the earliest wall paintings in the Annexes, as established by M. Martens-Czarnecka (2011: 235-260). This is also the time of a major overhaul in the monastery church (Jakobielski 2010: 89) and the time of operation of the commemorative complex of St Anna, according to a visitor's inscription dated AD 1074/1075 (Lajtar 2014: 286). The use of the courtyard is, therefore, not only contemporary to the use of rooms on the ground floor of the Main Building and to the last phases of use of building H.B.01, but also to major building projects in the Annexes. In the 13th century AD, the functioning of the Cooking Area and the subsequent building of the complex SW-E.16 also occurred parallel to further developments in the Annexes, although some rooms (SW-E.15) and buildings (ground floor of the Main Building) fell into disuse.

The successive phases of the courtyard, therefore, occur parallel to regular activity on Kom $\mathrm{H}$. The question when the monastery ceased to function remains unanswered. The lack of dates past the mid-13th century does not exclude later 13th- and early 14th-century AD occupation. Mamluk raids in the second half of the 13th century AD may have brought an end to the monastery, but activity in the area, including Courtyard A, may have continued in one form or another. The occupation of the dwelling complex SW-E.16 in phase VIIIB could have occurred after the monastery no longer functioned, possibly at the end of the 13th or in the 14 th century AD.

Therefore, changes in Courtyard A in all phases of use are tied to changes occurring in other parts of the monastery. Ovoid structures raised using re-claimed materials, bearing characteristics of temporary features, are a permanent element of the monastery for several centuries. This manner of building, with thin walls on carelessly laid foundations of baked bricks, are not unique to the monastery on Kom H. Similar structures have also been recorded at Serra East in contemporary contexts and similar setting (Bruce Williams, personal communication). It seems to be a construction method used in open areas to build dwellings and service spaces. Such structures preserve poorly and are therefore difficult to trace in the archaeological record, but are nonetheless important evidence for building traditions and organization of space in Late Medieval Makuria.

\section{Importance of ${ }^{14} \mathrm{C}$ Dating for the Pottery Studies and Chronology in Old Dongola}

The results of ${ }^{14} \mathrm{C}$ analyses generally correspond to the ceramic dating of Courtyard $\mathrm{A}$, which was attributed to the 11th-14th century AD on the basis of the aforementioned chronological systems. The beginning of activity in Courtyard A may be as early as the 11th century AD, as indicated by Samples H.1 and H.7, and while none of the deposits were carbon-dated to later than the 13th century AD, it is still possible to connect the highest strata, from which no samples were collected, with the 14th century AD.

Although the general chronological framework did not change in the light of the results of ${ }^{14} \mathrm{C}$ dating, more precise dates can be established for material from individual contexts from which samples were collected. For instance, Phase VIIIA (layer 66 in SW-E.15) was pottery-dated 
from the end of the 12 th to the end of the 13 th century $\mathrm{AD}$, while the ${ }^{14} \mathrm{C}$ datings of samples from the Cooking Area stage and from the Dwelling stage point to a date of this phase at the end of the 13 th century AD. Table 3 shows the correlation between the results of ${ }^{14} \mathrm{C}$ analyses and the dates for the ceramics from Courtyard A established on the basis of the two aforementioned chronological systems.

\section{Pottery Dating Markers in the Light of ${ }^{14} \mathrm{C}$ Dates from Courtyard A}

${ }^{14} \mathrm{C}$ dating results from Courtyard A permit to assign absolute dates to the phases in the relative chronology of the ceramics. The most distinctive forms in those assemblages can be used as dating markers for other archaeological contexts and as such they can aid in dating other finds. Also, changes in the pottery can be placed within a more precise chronological framework.

In the case of the Dongolese amphorae found in the ${ }^{14} \mathrm{C}$-dated deposits, the dates place the established linear sequence in an absolute chronology. They represented three types, E, F, and G, according to the typology established by Krzysztof Pluskota (2005: fig 8). Specimens of type F (Figure 5 HDd.15.487) and type G (Figure 5 HDd.17.1053) were discovered in layers assigned to the Open Courtyard stage dated to the mid-11th-12th centuries AD, and an amphora belonging to type E (Figure 5 HDd.16.320) came from a context attributable to the Cooking Area stage, dated to the 13th century AD. According to Pluskota's sequence, type E should be the earliest of these forms, while the stratigraphic sequence supported by the ${ }^{14} \mathrm{C}$ dating places it in the latest stages of the Dongolese amphorae production. It is possible that these containers were, at least in part, secondary deposits in the carbon-dated layers. On the other hand, the contexts of amphorae that served as groundwork for Pluskota's typology had a relative chronology and no absolute dates. The ${ }^{14} \mathrm{C}$ dates from Courtyard $\mathrm{A}$, therefore, do not alter the established chronological sequence of these containers. However, it cannot be excluded that the evolution of Dongolese amphorae was non-linear and some types occurred parallel to others. More series of ${ }^{14} \mathrm{C}$ dates are necessary in order to correlate absolute dates with the appearance of particular types of these containers.

The relative chronology of the evolution of other transport vessels like jars was confirmed by the ${ }^{14} \mathrm{C}$ dating. Earlier forms (Figure $5 \mathrm{HDd}$.15.488) had more slender and thinner walls of necks than later specimens (Figure 5 HDd.16.450). Moreover, jars with purple-painted necks appear to be connected with the 11th-13th centuries AD (Figure 5 HDd.17.854).

Also for tableware, the relative chronological sequence for the evolution of shapes was confirmed with ${ }^{14} \mathrm{C}$ analysis. Fairly shallow and open-mouthed cups found in Courtyard A are dated to the 11 th-13th century AD (Figure 5 HDd.17.1069). They fill a gap in the development sequence established by W.Y. Adams, which fell in the Classic Christian Period, or 850-1100 AD (1986: Fig 17). After that time, these shallow forms were replaced by cylindrical cups (Figure 5 HDd.16.425, HDd.16.411) in $1200 \mathrm{AD}$, the Late Christian Period (Adams 1986: Fig 17). The painted decoration of the cylindrical cups from Courtyard A represents a local variant of the Lower Nubian Style N.VIA, dated to 11501350 AD (Adams 1986: Fig 100). The presented specimens were found in a deposition layer of the Dwelling Complex phase, dated to the end of the 13th century AD, which confirms the relative chronology based on the style of decoration. Over time, those forms 


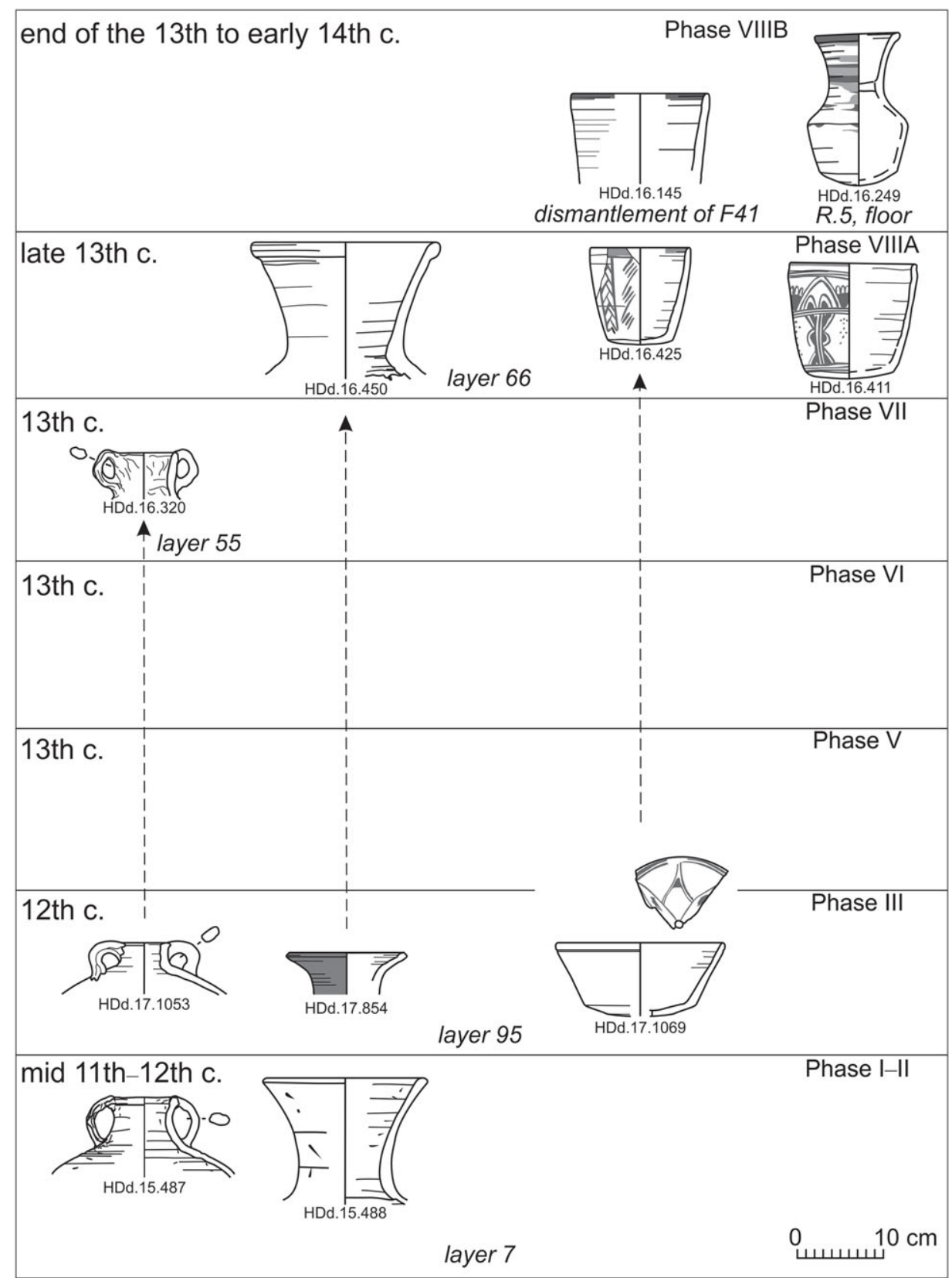

Figure 5 Pottery dating markers in ${ }^{14} \mathrm{C}$ dated contexts from Courtyard A: amphorae, cups, and a qulla (drawn by $\mathrm{K}$ Danys). Arrows mark continuation of the presence of presented types in other phases.

became taller (Figure 5 HDd.16.145) and more slender, and they began to receive characteristic surface treatment: white or cream slip and red rim band. In the relative chronology of previous Dongolese pottery finds, their appearance has been dated to the 13th century AD and in this period at Old Dongola the tall cylindrical cups are a common form. 
A single find of a small qulla (Figure $5 \mathrm{HDd}$.16.249) finds no parallels in the material previously excavated on this site. It was recovered from a context attributable to the Dwelling Complex stage, dated from the end of the 13th century to some point in the 14th century AD. A similar vessel was found during a survey conducted in the Dongola Reach and dated to the Terminal Dongola phase, or 1365-1504 AD (Phillips 2003: Pl 98e). The dating offered for the survey find may now be reconsidered given the presence of material from a secure context. The qulla from the survey may indeed be a later version of the one from Courtyard A, but it could also be a local yet contemporary variation of the shape.

${ }^{14} \mathrm{C}$ dating also offered a possibility to distinguish subdivisions among plates. A large form (Figure 6 HDd.15.517) with a thicker rim and decoration consisting of a red rim band, pendant triangles filled with crosshatching, and vertical elements with strokes and a meander-like pattern was one of the most common forms found in Courtyard A. The context corresponds to the Cooking Area stage (13th century AD), while according to the relative chronology and style-dating, it belonged to Lower Nubian Style N.VIA dated to 1150-1350 AD (Adams 1986: Fig. 100). It is noteworthy that another plate (Figure 6 HDd.16.432) represented the same style (N.VIA), but its context was part of the later Dwelling Complex stage dated to the end of the 13th century AD.

Vases with ledge like HDd.17.1078 (Figure 6) were discovered in a layer dated to the mid-11th12th century AD, but like in Lower Nubian Style N.IV A, the relative chronology of their decorative elements suggests that they might be dated earlier, to 850-950 AD (Adams 1986: Figs 100, 164-166), like other finds from Dongola. Thus, these specimens are rather secondary depositions in this context and their dating to a later period is not possible. In contrast, tableware with leaf-like medallions (Figure 6 HDd.17.1098) represents local, Dongolese pottery workshops dated mainly to the Post-Classic Christian Period (1100-1200 AD) on the basis of archaeological evidence (Pluskota 1994). Therefore, the dating for the contexts of finds from Courtyard A to the mid-11th-12th century AD confirms the results of previous investigations.

In the group of vessels used for cooking purposes, large flat baking plates, often identified with dokat (vessels used for baking traditional pancake bread called kisra), yielded interesting data. Changes observed in this group were connected with the fabric. Specimens discovered in layers contemporary to the context assigned to the Open Courtyard stage (mid-11th-12th century AD) were made of Nile silt tempered with organics. Later vessels, in turn, were exclusively made of Nile silt tempered with grog. They were also thick-walled and heavier than earlier specimens (Figure $7 \mathrm{HDd}$.15.520, HDd.16.455). The change in the manufacturing of handmade pottery can be placed within the 13th century AD.

Cooking pots dated to be younger than the 13th century AD have the same characteristics of the fabric. The most common shape is spherical (Figure 7 HDd.16.466), with a rough lower body and smoothed upper part, and with a circumferential row of stamps that separated these two zones. The collected evidence provides a dating for these vessels at the end of the 13th century AD. However, these pots appear in archaeological layers of a later date as heavily burnt specimens, often lacking a base and placed in sand alongside structures. Their context and state of preservation suggests they were used for a long time and, even when they were no longer usable for cooking purposes, they had a different function, e.g., as supports for other round-based vessels or as storage containers. 


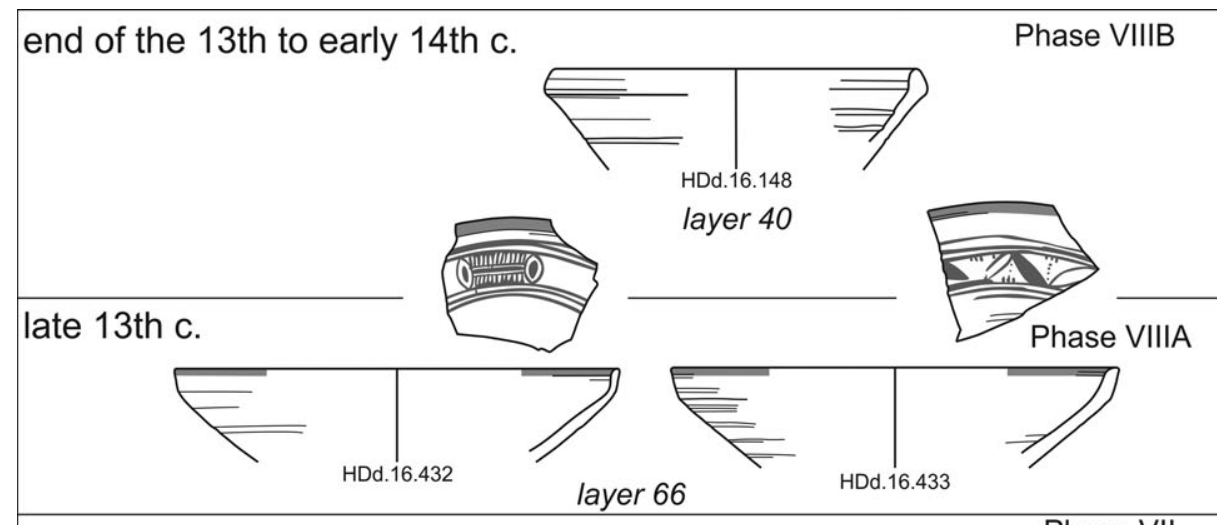

13th c.

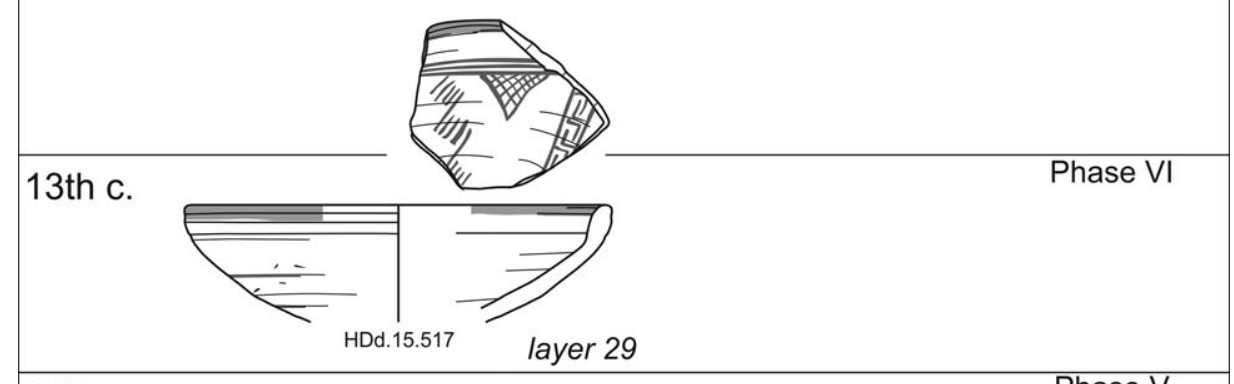

13th c.

Phase V

12th c.
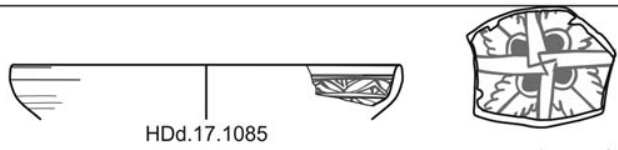

layer 95

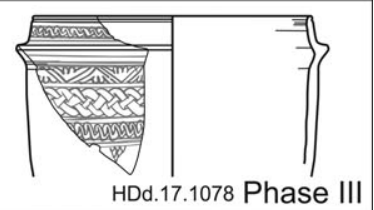

mid 11th-12th $\mathrm{c}$.

Phase I-II

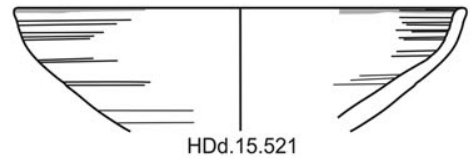

layer 7

نسسس $10 \mathrm{~cm}$

Figure 6 Pottery dating markers in ${ }^{14} \mathrm{C}$ dated contexts from Courtyard A: plates and a vase (drawn by K Danys).

\section{CONCLUSIONS}

${ }^{14} \mathrm{C}$ dating has a potential for validating the development sequences of pottery. Pottery analysis requires a consideration of the archaeological context and the likelihood of secondary deposition of the material. Problems with establishing a dating for the ceramics were indicated by W. Y. Adams for contexts he described as "contaminated". To avoid mistakes 


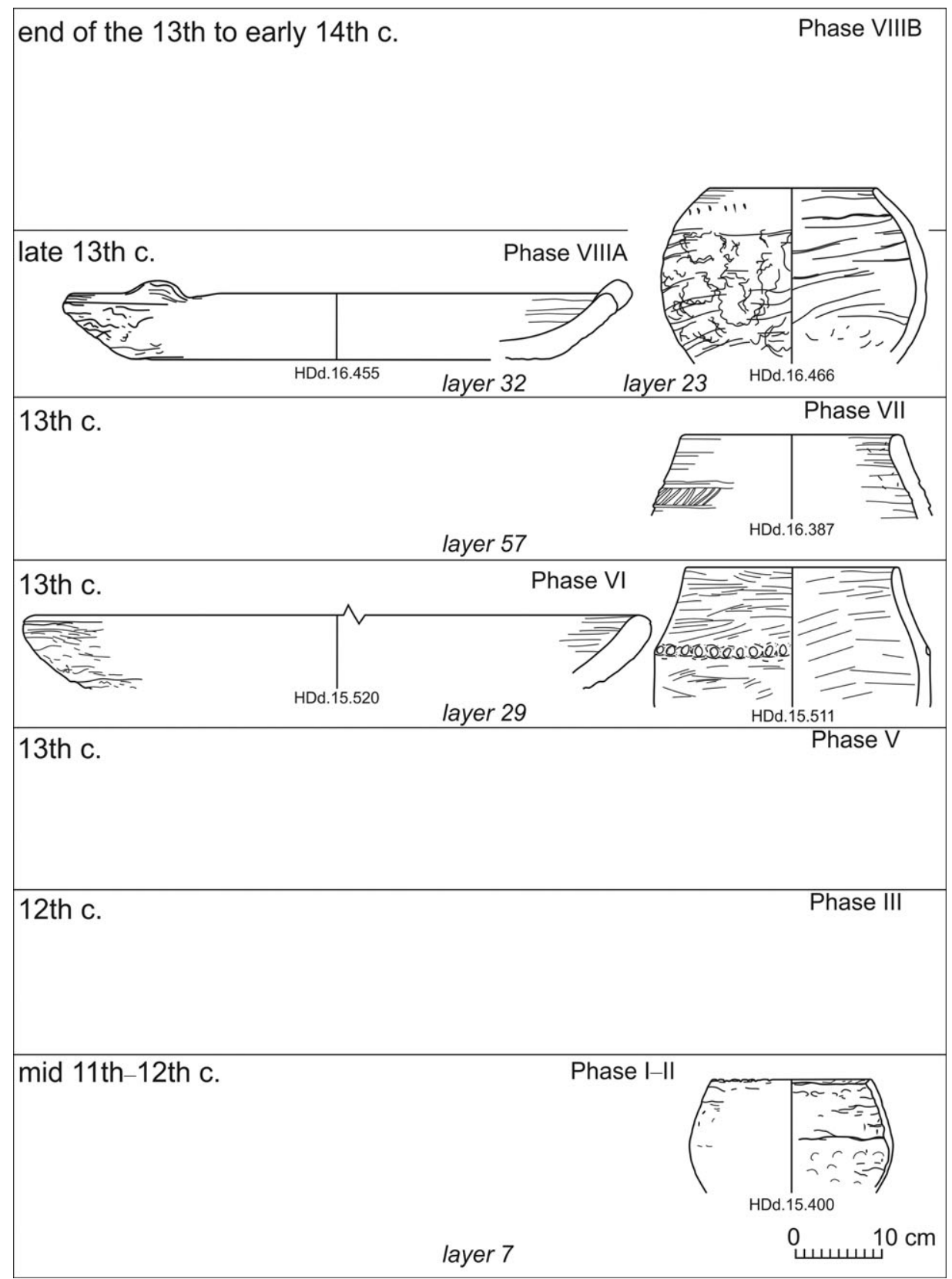

Figure 7 Pottery dating markers in ${ }^{14} \mathrm{C}$ dated contexts from Courtyard A: handmade baking plates and cooking pots (drawn by K Danys).

arising from wide chronological spans caused by redeposited and reused vessels from earlier periods, it is necessary to create more pottery sequences anchored in ${ }^{14} \mathrm{C}$ dates. Comparisons between them should lead to establishing absolute dates of their manufacture and use, which can then be used for assigning more precise dates to assemblages of Christian Nubian pottery. 


\section{ACKNOWLEDGMENTS}

Excavation work in Old Dongola in the 2014-2018 seasons was conducted by an expedition of the Polish Centre of Mediterranean Archaeology, University of Warsaw, with funding from the Qatar-Sudan Archaeological Project (QSAP.A.31). The works, directed by Włodzimierz Godlewski, were conducted by Dorota Dzierzbicka and Agata Deptuła. The authors are grateful to Tomasz Goslar from the Poznań Radiocarbon Laboratory for his advice and comments, which greatly improved this paper. Thanks are also due to the anonymous reviewers for their valuable suggestions and constructive criticism. The authors are grateful to ABEIPS for covering the open access publication charges.

\section{REFERENCES}

Adams WY. 1986. Ceramic Industries of Medieval Nubia. Memoirs of the UNESCO Archaeological Survey of Sudanese Nubia 1. Lexington (KY): University Press of Kentucky.

Brock F, Higham T, Ditchfield P, Ramsey C. 2010. Current pretreatment methods for AMS radiocarbon dating at the Oxford Radiocarbon Accelerator Unit (ORAU). Radiocarbon 52(1):103-112.

Bronk Ramsey C. 2001. Development of the radiocarbon calibration program OxCal. Radiocarbon 43(2A):355-363.

Bronk Ramsey C. 2009. Dealing with outliers and offsets in radiocarbon dating. Radiocarbon 51(3):1023-1045.

Bronk Ramsey C. 2017. Methods for summarizing radiocarbon datasets. Radiocarbon. 59(2): 1809-1833.

Bronk Ramsey C, Lee S. 2013. Recent and planned developments of the program OxCal. Radiocarbon 55(2-3):720-730.

Czernik J, Goslar T. 2001. Preparation of graphite targets in the Gliwice Radiocarbon Laboratory for AMS ${ }^{14} \mathrm{C}$ dating. Radiocarbon 43(1):283-291.

Danys K. 2016. Pottery from Dongola: a stratigraphic assemblage from Unit B.I.41. PAM 25:761-779.

Danys K. 2018. Introductory Remarks on the Pottery Finds from Courtyard-A in the Monastery of St Anthony at Old Dongola. In: Godlewski W, Dzierzbicka D, Lajtar A editors. Dongola 2015-2016. Excavation, Fieldwork and Site Management. PCMA Excavation Series 5. Warsaw: University of Warsaw Press. p. 101-106.

Danys K. Ceramics from Old Dongola. In preparation.

Drzewiecki M. 2010. Excavating the curtain wall in Banganarti in 2007. PAM 19:342-358.

Drzewiecki M. 2017. The medieval fortifications at Banganarti after the 2016 season. PAM 26(1): 301-309.

Dzierzbicka D. Forthcoming. Food in Courtyard A at the monastery on Kom $\mathrm{H}$ in Old Dongola, Sudan. In: El Dorry M, editor. Food and drink in Egypt and Sudan. Cairo: Imprimerie IFAO.
Dzierzbicka D, Deptuła A. 2018. Courtyard A at the Monastery on Kom H in Dongola: Fieldwork in 2014-2016. In: Godlewski W, Dzierzbicka D, Lajtar A, editors. Dongola 2015-2016. Excavation, Fieldwork and Site Management. PCMA Excavation Series 5. Warsaw: University of Warsaw Press. p. 79-100.

Eigner D, Karberg T. 2011. W.A.D.I. 2011: Die Bauaufnahme der Ruine Umm Ruweim 1. MittSAG. 22:69-84.

Gazda D. 2008. The monastery church on Kom H in Old Dongola after two seasons of excavations in 2006. PAM 18:349-360.

Godlewski W. 2013. Archbishop Georgios. Sociopolitical change in the kingdom of Makuria in the second half of the 11th century. PAM 22:663-677.

Godlewski W. 2015. Architecture of the Central Hall. In: Godlewski W, Dzierzbicka D, editors. Dongola 2012-2014. Excavation, fieldwork and site management. PCMA Excavation Series 3. Warsaw: University of Warsaw Press. p. $15-24$.

Godlewski W. 2018. The monastery church. In: Godlewski W, Dzierzbicka D, Lajtar A, editors. Dongola 2015-2016. Excavation, fieldwork and site management. PCMA Excavation Series 5. Warsaw: University of Warsaw Press. p. 15-30.

Godlewski W, Danys-Lasek K, Osypińska M. 2015. Palatial Building SWN.B.I and earlier relics of Buildings SWN.B.IV and SWN.B.X. In: Godlewski W, Dzierzbicka D, editors. Dongola 2012-2014. Excavation, fieldwork and site management. PCMA Excavation Series 3. Warsaw: University of Warsaw Press. p. 65-84.

Goslar T, Czernik J, Goslar E. 2004. Low-energy ${ }^{14} \mathrm{C}$ AMS in Poznan Radiocarbon Laboratory, Poland. Nuclear Instruments and Methods in Physics Research B 223-224:5-11.

Grzymski K. 1990. Excavations at Hambukol (Upper Nubia): 1987 and 1988 seasons. JARCE 27: 139-163.

Hamilton D. 2012. Radiocarbon dates at Jebel Kadamusa. In: Osman A, Edwards DN, editors. 
The archaeology of a Nubian frontier. Survey on the Nile Third Cataract. Leicester: Mauhaus Publishing. p. 208-210

Jakobielski S. 1997. Old Dongola. Kom H, Site NW. PAM 8:161-168.

Jakobielski S. 2001. 35 years of Polish excavations at Old Dongola. A factfile. In: Jakobielski S, Scholz PO, editors. Dongola-Studien: 35 Jahre polnischer Forschungen im Zentrum des makuritischen Reiches. Bibliotheca Nubica et Aethiopica 7. Warsaw: ZAŚ PAN. p. 357-366.

Jakobielski S. 2008. The Holy Trinity Monastery in Old Dongola. In: Godlewski W, Łajtar A, editors. Between the Cataracts. Proceedings of the 11th Conference for Nubian Studies. Warsaw University, 27 August-2 September 2006. Part 1: Main papers. PAM Supplement Series 2.1. Warsaw: Warsaw University Press. p. 283-302.

Jakobielski S. 2010. The Holy Trinity Monastery in Old Dongola. Excavations 2002/2003-2006. Gdańsk Archaeological Museum African Reports. 6:69-90.

Jakobielski S., Martens-Czarnecka M. 2008. Old Dongola. Fieldwork, seasons 2005/2006 and 2006. PAM 18:325-342.

Lajtar A. 2002. Georgios, Archbishop of Dongola $(† 1113)$ and his epitaph. In: Derda T, Urbanik J, Węcowski M, editors. Euergesias Charin: studies presented to Benedetto Bravo and Ewa Wipszycka by their disciples. JJP Supplement 1. Warsaw: Raphael Taubenschlag Foundation. p. 159-192.

Lajtar A. 2014. Dongola 2010: epigraphic report. PAM 23(1):285-295.

Lajtar A, van der Vliet J. 2017. Empowering the dead in Christian Nubia. The texts from a medieval funerary complex in Dongola. Journal of Juristic Papyrology, supplement 32. Warsaw: Raphael Taubenschlag Foundation.

Martens-Czarnecka M. 2011. The wall paintings from the monastery on Kom H in Dongola (translated by B.M. Gostyńska). Nubia 3; Dongola 3; PAM Monograph Series 3. Warsaw: Warsaw University Press.

Michałowski K. 1996. Polish excavations at Old Dongola: first season, November-December 1964. Kush 14:289-299.

Obłuski A, Ochała G, Korzeniowska M, Maślak S, Calaforra-Rzepka C, and Mahmoud Z. 2017. The winter seasons of 2013 and 2014 in the Ghazali monastery. PAM 26(1):367-398.

Paner H, Pudło A. 2010. Settlements in the Fourth Cataract GAME concession in the light of radiocarbon analysis. Gdańsk Archaeological Museum Archaeological Reports 7: 131-146.

Phillips J. 2003. An overview of the ceramics. In: Żurawski B, editor. Nubia II. Southern Dongola Reach Survey 1: survey and excavations between Old Dongola and EzZuma. Warsaw: Neriton. p. 387-437.

Pluskota K. 2005. Amphorae from Old Dongola. Evolution of local products (exploration of kiln R1 F). Gdańsk Archaeological Museum Archaeological Reports 3:227-232.

Pluskota K. 1994. Old Dongola - Kiln R 2 (PostClassic Christian Pottery Deposit). Nubica III(1):361-377.

Pluskota K. 2001. The kiln sites of Old Dongola. In: Jakobielski S, Scholz PO, editors. DongolaStudien: 35 Jahre polnischer Forschungen im Zentrum des makuritischen Reiches. Bibliotheca Nubica et Aethiopica 7. Warsaw: ZAŚ PAN. p. 357-366.

Reimer P, Bard E, Bayliss A, Beck J, Blackwell P, Bronk Ramsey C, Buck CE, Cheng H, Edwards RL, Friedrich M, et al. 2013. IntCal13 and Marine13 radiocarbon age calibration curves $0-50,000$ years cal BP. Radiocarbon 55(4):1869-1887.

Stuiver M, Polach HA. 1977. Discussion: reporting of ${ }^{14}$ C data. Radiocarbon 19(3):355-363.

Tomlinson PB, Huggett BA. 2012. Cell longevity and sustained primary growth in palm stems. Amer. J. Bot. 99:1891-1902.

Wacker L, Němec M, Bourquin J. 2010. A revolutionary graphitisation system: Fully automated, compact and simple. Nuclear Instruments and Methods in Physics Research Section B: Beam Interactions with Materials and Atoms 268(7-8):931-934.

Wotzka HP, Goedicke C, Michels M. 2012. Boni Island radiocarbon and OSL dates. In: Wotzka HP, editor. Proceedings of the Third International Conference on the Archaeology of the Fourth Nile Cataract: University of Cologne, 13-14 July 2006. Africa Praehistorica 22. Cologne: Heinrich Bart Institute. p. 137-176.

Żurawski B. 1999. Faith healing, philanthropy and commemoration in Late Christian Dongola. In: Emmel S, editor. Ägypten und Nubien in spätantiker und christlicher Zeit: Akten des 6. Internationalen Koptologenkongresses, Münster, 20-26 July 1996. Vol. 1. Sprachen und Kulturen des Christlichen Orients 6/1. Wiesbaden: Reichert. p. $423-448$.

Żurawski B. 2007. Fourth Cataract survey and excavations in Shemkhiya, Dar el-Arab and Saffi Island. PAM 17:323-335. 